\title{
Mariusz GuZeK
}

\section{Krakatit i Ciemne słońce - adaptacje prozy Karela Čapka autorstwa Otakara Vávry}

„Otakar Vávra, przedwojenny komunista, przeżył nazistowską okupację $\mathrm{w}$ ten sposób, że kręcił jeden film za drugim, a kolaborancka władza Protektoratu obdarowywała go nagrodami i zaszczytami" - tak scharakteryzował powojenny status twórcy Krakatitu Josef Škvorecký - niezwykle bystry obserwator i uczestnik dziejów czechosłowackiego filmu ${ }^{1}$, a ponadto jeden z czołowych powojennych nadwełtawskich intelektualistów. W roku 1948 Vávra miał już liczący się dorobek i to nie tylko z lat 1938-1945, kiedy pracował dla przemysłu filmowego Protektoratu Czech i Moraw (choć rzeczywiście był to najbardziej płodny okres jego twórczości) i przez niektórych uznawany był wręcz za klasyka. Mimo krytycznej uwagi Škvoreckiego o oportunistycznej postawie reżysera, należy zwrócić uwagę na niezwykle twórczą zasadę wyznawaną przez Vávrę - literatura była dla niego nie tylko nawozem umożliwiającym uprawę kinematograficznego poletka, ale jej związek z szukającym własnej formuły kinem traktował wręcz organicznie ${ }^{2}$. Zanim sięgnął po Krakatit Karela Čapka, narracji kinematograficznych szukał w tekstach Aloisa Jiráska, Ladislava Stroupežnickiego, Karela Matěja Čapka-Choda ${ }^{3}$ czy Zigmunda Wintera.

Josef Škvorecký, Jiří Menzel a historie Ostře sledovaných vlaků, [w:] tenże, Nejdražší umĕni a jiné eseje o filmu. Spisy 37, Books and Cards, Praha 2010, s. 206. Tłumaczenia z języka czeskiego, jeśli nie zostało zaznaczone inaczej, są mojego autorstwa - M. G.

2 Taki pogląd został także uwzględniony w opracowaniach encyklopedycznych pisanych z zachodniej perspektywy, patrz: Efraim Katz, The Macmillan International Film Encyclopedia, New Edition, Macmillan Publishers, New York 1994, s. 1407; Jean-Loup Passek, Dictionnaire du Cinéma L-Z, Larousse, Paris 1995, s. 2219.

3 Halina Smolińska opracowując dokumentację po polskiej premierze Ciemnego słońca, błędnie przypisała Karelowi Čapkowi autorstwo powieści Humoreska i Turbina, które zostały przeniesione na ekran przez Otakara Vávrę w okresie Protektoratu Czech i Moraw. W rzeczywistości są one adaptacjami powieści popularnego przed drugą wojną 
Rok premiery filmu - 1948 - był przełomowym w dziejach powojennej Czechosłowacji, co uwidoczniły zmiany na wszelkich polach społeczno-politycznej szachownicy, także w przemyśle filmowym. Należy bowiem pamiętać, że produkcja z lat wcześniejszych - między zakończeniem wojny (1945) a komunistycznym przewrotem (1948) - nie była bynajmniej nastawiona jedynie na prymitywnie uproszczoną propagandę. Świadectwem tego były takie filmy, jak zdobywca Złotego Lwa na Międzynarodowym Festiwalu Filmowym w Wenecji - dramat według powieści Marii Majerovej Syrena (Siréna) w reżyserii Karela Steklego czy Dni zdrady (Ulopená hranice) Jiř́iego Weissa. Zdaniem Petera Hamesa do zestawu filmów wolnych od propagandowego stygmatu należałoby koniecznie wprowadzić Vávrowego Krakatita ${ }^{4}$. Sam Vávra, którego lewicowe przekonania i pragmatyczne wyczucie politycznego przełomu już w 1945 r. przywiodły w szeregi Komunistycznej Partii Czechosłowacji, wykazywał produkcyjną aktywność, zręcznie poruszając się pomiędzy najważniejszym projektem swego "osobliwego reżyserskiego życia” - filmowymi adaptacjami narodowej literatury a komentowaniem bieżącej sytuacji politycznej. Te pierwsze reprezentowane były przez ekranizację powieści Zikmunta Wintera: Rozina sebranec (1945) i Nezbedný bakalář (1946), Předtucha (1947) na podstawie opowiadania Marii Pujmanovej i oczywiście Krakatit Čapka. Drugi zaś nurt tworzyły dokumenty: Návrat presidenta dr. Edvarda Beneše do Prahy (1945), Vlast vítá (1945) oraz złożony z dokumentalnych kronik obraz montażowy Cesta $k$ barikádám, prezentowany także pod tytułem Pravda vítézi (1946).

Otakar Vávra miał gotowy scenariusz adaptacji powieści Karela Čapka z 1924 r. - napisał go wspólnie z bratem Jaroslavem na długo przed wydarzeniami lutowymi, które przenicowały system polityczny i wprowadziły monopolistyczną władzę partii komunistycznej. Zresztą o sięgnięciu po tę dystopijną opowieść myślał już od dłuższego czasu ${ }^{5}$. Twórca szukający wspólnego mianownika, pola korespondencji między filmem a literaturą, musiał sięgnąć po bogatą twórczość autora Inwazji jaszczurów. Przed rokiem 1948 też czyniono takie próby, ale były one w najlepszym razie - mało oryginalne ${ }^{6}$. Otakar Vávra i Karel Čapek planowali zresztą

światową naturalisty Karela Matěja Čapka-Choda, patrz: Ciemne słońce, „Filmowy Serwis Prasowy" 1981, nr 10, s. 5.

4 Peter Hames, Czech and Slovak Cinema. Theme and Tradition, Edinburgh University Press, Edinburgh 2009, s. 77.

5 Otakar Vávra, Paméti aneb moje filmové 100 letí, Nakladatelství BVD, Praha 2011, s. 128.

6 Pierwszym zrealizowanym na podstawie prozy Karela Čapka filmem była adaptacja jednej z jego bajek, Zlatý klíček, nakręcona w 1922 r. przez Jaroslava Kvapila, drugim - dramat sceniczny Loupežnik z 1931 r. w reż. Josefa Kodička. Sześć lat później Hugo Haas przeniósł na ekran kolejny utwór dramatyczny, Bilá nemoc, a w 1938 r. pow- 
wspólne przedsięwzięcie jeszcze w czasach pierwszej republiki. Miała to być adaptacja opowiadania Egona Erwina Kischa Wniebowstapienie Szubienicznej Tonki (Nanebevstoupení Tonky Šibenice), którą wcześniej przeniósł na ekran w roku 1930 Karen Anton, obsadzając w roli głównej słoweńską aktorkę Itę Irinu (właściwie Tamarę Djordjević), a rolę jej matki powierzając Wierze Baranowskiej, znanej z klasycznego obrazu radzieckiej szkoły montażu - Matki (1926) Wsiewołoda Pudowkina ${ }^{7}$. Stąd nie ma powrotu niesłusznie uznawany jest za pierwszy dźwiękowy film w historii czechosłowackiej kinematografii ${ }^{9}$. Sam Vávra współpracę z autorem Krakatita wspominał następująco:

Przed nadejściem nazizmu napisaliśmy wraz z Čapkiem scenariusz według Tonki Šibenice Kischa. Choć Čapek sam już nie chciał pisać, to jednak pomysł ten pochłonął go w całości. Gdybyście widzieli, jak ten wielki i sławny pisarz każdego ranka miał gotową wersję tego, o czym dzień wcześniej dyskutowaliśmy. Takiej pracowitości i dyscypliny nigdy w życiu nie widziałem. Scenariusz powstał, ale ze zrozumiałych względów nie mogłem go zrealizować ${ }^{10}$.

Na tle nawet tak zróżnicowanego piśmiennictwa, jak dorobek Karela Čapka, Krakatit wydaje się powieścią wyjątkową, choć z całą pewnością nie najdoskonalszą. Wznawiana po dziesięcioleciach od premiery, ewokowała skrajne opinie recenzentów. Jan Wyka przy okazji pierwszego polskiego wydania powojennego napisał: „Krakatit jest powieścią chybioną. Każdy wybitny pisarz ma prawo do nieudanego utworu i nie on mu zapewnia zainteresowanie dla jego twórczości na długi okres po uroczystym nekrologu"11, zaś omawiając następną edycję powieści, Edward Madany konkludował:

stała ekranizacja Hordubala, pod którą podpisał się Martin Frič. To on po wojnie, na rok przed realizacją Vávrowego Krakatita, wyreżyserował Čapkovy povídky. Nie sposób nie wspomnieć o dwóch brytyjskich telewizyjnych ekranizacjach dramatu science-fiction R.U.R. z 1938 i 1948 r. Patrz: Vladimir Bystrov, Karel Čapek a film, „Film a divadlo” 1958, č. 24, s. 17.

7 Český hraný film II. 1930-1945. Czech Feature Film II. 1930-1935, Národní Filmový Archiv, Praha 1998, s. 355. Patrz też: Jiř́i Voráč, Tonka Šibenice, „Iluminace” 1997, č. 4, s. 187-190.

8 Pod takim tytułem Tonka Šibenice Antona wyświetlana była w polskich kinach.

9 W rzeczywistości był to film niemy z dokręconymi w atelier Gaumont w Joinville pod Paryżem scenami śpiewanymi w trzech wersjach językowych: czeskiej, francuskiej i niemieckiej, patrz: Václav Březina, Lexikon českého filmu. 2000 filmů 1930-1996, Filmové nakladatelství Cinema, Praha 1996, s. 422.

10 Jak był znárodnĕn československý film. Rozhovor z časopisu „Film a doba”, [w:] Otakar Vávra 100 let, Millenium Publishing, Novela Bohemica, Praha 2011, s. 67.

11 Jan Wyka, Literackie rozbicie atomu, „Twórczość” 1960, nr 8, s. 120. 
Krakatit nie jest utworem pospolitym. Talent pisarski Čapka, wielka idea moralisty XX wieku wpisana w różne elementy konstrukcyjne i stylistyczne opowieści sprawiły, że powstał moralitet współczesny. Moralitet bardziej przemawiający dziś swoimi szlachetnymi założeniami niż siłą ostrzeżenia przed katastrofą nuklearną ${ }^{12}$.

Powieść Karela Čapka, jakkolwiek pomijana w zachodnich opracowaniach dotyczących klasyki gatunku ${ }^{13}$, utrzymana jest w konwencji fantastyki naukowej i wpisuje się $\mathrm{w}$ twórczy projekt pisarza reprezentowany przez wcześniejsze dramaty tworzone wspólnie z bratem Josefem: $Z \dot{z}$ ycia owadów (Ze života hmyzu, 1921), Adam Stwórca (Adam Stvořitel, 1927), i samodzielnie: R.U.R. Rossum's Universal Robots (1920), a także powieści Fabryka absolutu (Továrna na absolutno, 1921-1922), oraz późniejsze: w tym uznane za najlepsze jego dzieła: Inwazja jaszczurów (Válka s mloky, 1936) i Biała zaraza (Bílá nemoc, 1937). Zdaniem Joanny Czaplińskiej, znawczyni czeskiej fantastyki literackiej: „Krakatit jest kolejną przestrogą Čapka dla ludzkości, ale zawiera prekursorski dla późniejszej fantastyki naukowej motyw, odpowiedzialności naukowca za następstwa swoich poczynan'"14.

Stan gorączkowego napięcia towarzyszył Capkowi podczas pisania powieści, która powstawała z trudem i bardzo długo. Dolegliwości fizyczne związane z rzadko spotykaną bolesną chorobą zwapnienia kręgosłupa, po dziś figurującą w czeskich książkach medycznych jako „przypadek Čapka”"15, a nade wszystko niepokoje dotyczące związku z Olgą Scheipflugovą, spowodowały, że ta fantastyczna opowieść ma

12 Edward Madany, Moralitet wieku atomowego, „Nowe Książki” 1974, nr 20, s. 47.

13 James Gunn w szóstym, niepublikowanym w Polsce tomie swojej antologii The Road to Science Fiction, w rozdziale poświęconym Europie Wschodniej, obok fragmentów książek Josefa Nesvadby, Stanisława Lema, Alexandra Krämera i Ovida S. Crohmlniceanu cytuje również epilog z Čapkowego dramatu R.U.R., patrz: The Road to Science Fiction, vol. 6: Around the Words, ed. James Gunn, White Wolf, Stone Mountains 1998, s. 267-276. Ten utwór sceniczny James Gunn wymienia też w Chronologii science fiction zamieszczonej w polskiej edycji swej antologii, patrz: Droga do science fiction. Od Wellsa do Heinleina, t. 2, wybór, przedm. i tło hist. James Gunn, Wyd. „Alfa”, Warszawa 1986, s. 492. Natomiast Stanisław Lem znacznie bardziej niż Krakatit cenił sobie takie powieści Čapka, jak Fabryka absolutu i Inwazja jaszczurów, patrz: Stanisław Lem, Fantastyka i futurologia, t. 2, Dzieła, t. XXIV, Biblioteka "Gazety Wyborczej”, Warszawa 2009, s. 100, 155, 186. Pozytywną i obszerną prezentację Krakatitu znajdziemy natomiast w książce Richarda Bleilera, Science fiction writers. Critical studies on the major authors from the early nineteenth century to the present day, Charles Scribner's Sons, New York 1999, s. 170.

14 Joanna Czaplińska, Dziedzictwo robota. Wspótczesna czeska fantastyka naukowa, Wyd. Naukowe Uniwersytetu Szczecińskiego, Szczecin 2001, s. 46.

15 Halina Janaszek-Ivaničkowá, Karol Čapek czyli dramat humanisty, Wiedza Powszechna, Warszawa 1962, s. 63. 
wiele autobiograficznych odniesień. Dość mocno wyeksponowany wątek erotyczny dotyczący relacji między głównym bohaterem powieści, inżynierem Prokopem a księżniczką Willie ma ukryty sens. Prawdopodobnie postać powieściowej księżniczki zainspirowana została osobą córki profesora brneńskiego uniwersytetu Věry Hrůzovej, która, po krótkim okresie zażyłości z Čapkiem, ostatecznie wyszła za mąż za właściciela młyna we wsi Skalice - Josefa Skoupila, o czym mogą świadczyć zapiski pisarza opublikowane pod koniec lat 70. ubiegłego stulecia ${ }^{16}$. Pisanie Krakatitu zostało przerwane - Čapek wyjechał za granicę, a owocem jego kilkumiesięcznych peregrynacji były publikowane w Lidovych novinach felietony podróżnicze zatytułowane Listy $z$ Włoch, niedawno udostępnione po raz pierwszy w Polsce w tomie Listy z podróży. Wędrówki po Półwyspie Apenińskim, podczas których odwiedził m.in. Sienę, Orvieto, Palermo i San Marino, sprawiły, że zatęsknił za Pragą, gdzie mieszkał oraz doliną rzeki Úpy, gdzie w Malých Svatoňovicach przyszedł na świat i się wychował. Żegnając się z czytelnikami włoskiego cyklu podróżnych felietonów, wyraźnie zaznaczył: „Bo u nas, moi drodzy, u nas także jest pięknie: równiny i góry, lasy i woda, i czego dusza zapragnie; i być może z czasem tam również będzie wielka obfitość obrazów i rzeźb, i dziwów nad dziwy, sztuka bowiem jest wielka"17.

Powieść, którą wydał w 1924 r. znany pisarz, poeta i publicysta Otakar Štorch-Marien w swojej oficynie Aventinum, pozornie wydawała się fantastyczną opowieścią o wynalazku straszliwego materiału wybuchowego, mogącego zniszczyć cały świat. Narracja, utrzymana w stylu popularnych sensacyjnych zeszytowych historyjek, wypełniona była przygodami, jakie przeżywa młody inżynier Prokop, poszukujący ukradzionego, tajemniczego preparatu krakatitu, zawdzięczającego swą tajemniczą nazwę wulkanowi na wyspie Krakatau w Cieśninie Sundajskiej, którego erupcja w 1883 r. była jednym z największych kataklizmów XIX w. Akcja skoncentrowana została - jak pisze w monografii pisarza František Buriánek - wokół następującej strategii: bohater powieści, podobnie jak bohaterowie bajek, musi stawić czoła trzem niebezpieczeństwom - oprzeć się pokusom, odnaleźć siebie i uratować świat ${ }^{18}$. Zasadniczy sens powieści ujawnił się dopiero w zakończeniu, kiedy zmęczony i nieszczęśliwy Prokop spotyka na wpół bajkowego dziadka, prostego,

${ }^{16}$ Jiří Sedláček, Historie: misto, kde vznikal Krakatit, http://neviditelnypes.lidovky.cz/historie -misto-kde-vznikal-krakatit-d75-/p_scifi.asp?c=A070124_212055_p_scifi_hpe (dostęp: 12.10.2011).

17 Karel Čapek, Listy z podróży, tłum. Piotr Godlewski, Wyd. W.A.B., Warszawa 2010, s. 65.

18 František Buriánek, Karel Čapek, Melantrich, Praha 1978, s. 147. 
mądrego i życzliwego, który prezentuje mu humanistyczny i uniwersalny porządek wszechrzeczy. Słyszy z jego ust: „twórca, wynalazca, który chce dokonać wielkich rzeczy i dla nich poświęca swój ludzki wymiar, nie doświadczy nigdy miłości, nie odnajdzie sensu życia i nie zazna szczęścia"19. Ta konkluzja została uwzględniona w filmowej wersji z 1948 r.; obraz o trzydzieści lat późniejszy służył innej ideologii.

Otakar Vávra realizując Krakatit, musiał i chciał pogodzić dwa porządki - literacki i publicystyczny. Pierwszy wywodził się z powieściowej wizji Čapka, drugi z doświadczenia ostatniej wojny, a głównie z perspektywy masowej zagłady, której ucieleśnieniem był atomowy nalot na Hiroszimę i Nagasaki w sierpniu 1945 r. Jak ujął to Petr Bilík, omawiając perspektywę reżysera na tle całej sytuacji czeskiej kinematografii powojennej:

przerażające skutki bomby atomowej były znane z amerykańskiego ataku na Japonię i druga wojna światowa dodała naukowo-fantastycznemu tematowi wiarygodności. Karel Höger w roli Prokopa - inżyniera chemika - rozmyśla o możliwych konsekwencjach złego użycia swego wynalazku, materiału wybuchowego o nieznanej do tej pory sile. Wątpliwościom, jakie rodzą się na skutek wojennych dążeń światowych mocarstw przeciwstawione zostały pokojowe możliwości wykorzystania tytułowego krakatita. Vávra wzmocnił napięcie poprzez nadanie filmowi kształtu gorączkowej wizji inżyniera Prokopa i do Čapkowego humanizmu dodał apel o charakterze politycznej deklaracji ${ }^{20}$.

Bilík podkreślił, iż najistotniejszy zabieg, jaki w korespondencji z powieścią zastosował Vávra - ujęcie narracji w formę sennego majaku, gorączkowej maligny głównego bohatera - z jednej strony wzmocnił przekaz na podstawowym poziomie odczytania, z drugiej zaś, poprzez nawiązanie do faktury niemieckiego ekspresjonizmu, uczynił go niepokojąco wieloznacznym. "Jedną z najciekawszych właściwości stworzonego przez Vávrę filmu jest zatarcie granicy między jawą a snem, halucynacją a rzeczywistością. Poprzez odpowiednie operowanie obrazem i dźwiękiem Vávra pokonał nastręczające się trudności i niebezpieczeństwa związane z takim kształtowaniem wizji filmowej" ${ }^{21}$ - pisała krótko po premierze w korespondencji z Pragi dla polskiego tygodnika „Film” Nina Bonhardová, redaktorka bardzo popularnego tygodnika „Svět v obrazech”. Rela-

19 Tamże, s. 148.

20 Petr Bilík, Kinematografie po druhé svĕtové válce (1945-1970), [w:] Panorama českého filmu, sestavil Luboš Ptáček, Rubico, Olomouc 2000, s. 107.

21 Nina Bonhardová, Krakatit czyli bomba atomowa. Nowy film produkcji czechosłowackiej, „Film” 1948, nr 9, s. 4. 
cje między powieściowym oryginałem a ekranizacją omówiła także, dość wnikliwie i krytycznie, Barbara Olszewska, dla której pesymistyczna tonacja i brak jednoznacznego ideologicznie zakończenia nie odpowiadały wymaganiom, jakie stawia się ekranizacjom klasyki literackiej, szczególnie tym odczytywanym z perspektywy geopolitycznego porządku powojennego. Pytała ona:

czy film, który stadu rozwydrzonych bestii ludzkich przeciwstawia jedynie przerażoną twarz samotnego człowieka ma pozytywną wartość społeczną - należy wątpić. Wątpić należy również, czy Karol Czapek gdyby znał współczesny rozwój zagadnień atomowych, napisałby tego rodzaju powieść i zgodził się na chwiejną interpretację ${ }^{22}$.

Pomysł ujęcia opowiadania $\mathrm{w}$ ramę, jaką tworzy gorączkowy stan głównego bohatera, zaczerpnięty został z innej powieści Čapka Meteor

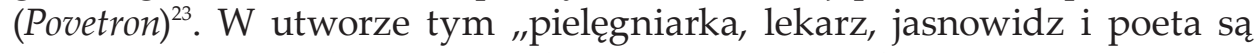
w stanie odgadnąć i odtworzyć sobie znaczną część losów umierającego cudzoziemca [...], które stają się kanwą służącą do różnej interpretacji jego egzystencji i jego czynów ${ }^{\prime 24}$. Losy inżyniera Prokopa mają też tajemnicę, której rozwiązanie może być przedmiotem rozmaitych strategii interpretacyjnych. Skoro przypisywane jest Vávrze wykorzystanie ekspresjonistycznej faktury, to uzasadnione będzie odwołanie się do Gabinetu doktora Caligariego (Das Kabinett der Doktor Caligari, 1919) w reż. Roberta Wiene, w którym fantastyczna narracja ujęta $\mathrm{w}$ ramę opowieści szaleńca czyni przekaz niejednoznacznym i metaforycznym ${ }^{25}$. Wzmacnia tę konstatację poprzedzający diegetyczny porządek napis wprowadzony przez reżysera: "akcja rozgrywa się w fantazji gorączkowego snu” i sekwencje szpitalne wkomponowane w fabułę na zasadzie interpolacji. Dodatkowego znaczenia nabiera w tym przypadku scena opuszczenia przez inżyniera Prokopa domu doktora Tomeša w Tynicach. Bohater, pakując swe rzeczy, spogląda przez okno - widzi małą chatkę, będącą jednocześnie pracownią wynalazcy i... zauważa samego siebie wchodzącego do jej pomieszczeń. A zatem znajdujemy się w podwójnym narracyjnym kleszczu - to nie rekonstrukcja tajemniczych wydarzeń snuta przez wszechwiedzącego narratora, a raczej

22 Barbara Olszewska, Krakatit. O dwóch obliczach Czapka, „Film” 1948, nr 18, s. 8.

23 Otakar Vávra, Paméti..., s. 128.

24 Hana Voisine-Jechova, Zwykły człowiek w utworach narracyjnych Karela Čapka, „Pamiętnik Słowiański" 1990, t. 40, s. 20.

25 Siegfried Kracauer, Od Caligariego do Hitlera. Z psychologii filmu niemieckiego, tłum. Eugenia Skrzywanowa, Wanda Wertenstein, Filmowa Agencja Wydawnicza, Warszawa 1958, s. 61. 
kolejny sygnał fantasmagorycznych wizji przejawiających się $\mathrm{w}$ postaci poplątanych majaków chorego pacjenta. Ponadto zwraca uwagę wykorzystanie metafory okna jako filtra do zaprezentowania punktu zwrotnego akcji. Karel Höger (aktor) widzi Karela Högera (inżyniera Prokopa) niczym uczestnik filmowego seansu bohatera akcji na ekranie.

Kiedy po latach Otakar Vávra po raz drugi sięgnął po powieść Čapka, realizując Ciemne słońce, bardzo mocno podkreślał metaforyczny charakter swego projektu z 1948 r. Jak sam twierdził, wielkie wojny, które poprzedziły powstanie dzieł (pierwsza - w przypadku literackiego Krakatita i druga - w przypadku jego filmowej adaptacji), zmieniły co prawda technologię pracy, ale nie zmieniły jej zasadniczego sensu przejawiającego się $\mathrm{w}$ rozdarciu między niewłaściwym wykorzystaniem osiągnięć naukowych a radością z osiągniętego rezultatu. Zmienne te wyraźnie osadzone są w kontekście epoki - od 1919 r., kiedy Ernst Rutherford przeprowadził pierwszą reakcję jądrową, do zniszczenia Hiroszimy i Nagasaki minęło nie tylko dwadzieścia pięć lat, ale zmieniła się koncepcja postępu naukowo-technicznego, dzięki któremu możliwa stała się przemysłowa organizacja zagłady $^{26}$. Karel Krejčí przyswajając polskiemu czytelnikowi sylwetkę twórczą Karela Čapka, zwrócił uwagę na istotny dla koncepcji utopijno-alegorycznego świata przedstawionego w powieści problem Boga. Porównując dwa powstałe w połowie trzeciej dekady XX w. utwory: Fabrykę absolutu (1922) i Krakatit (1924), zauważa dwa oblicza Boga, a właściwie dwóch Bogów.

W Fabryce absolutu jest to Bóg panteistyczny, wyzwolony z materii po rozbiciu atomu. Zagarnia cały świat, ale traci swą moc porządkującą i [...] prowadzi świat do chaosu, rozlewając z początku ideę powszechnej miłości i braterstwa, zmieniającą się jednak w fanatyzm sekciarski, powodujący straszną wojnę światową. Drugi Bóg z utopii Čapka jest o wiele prostszy, ale też o wiele mądrzejszy. Jest to w Krakaticie Bóg biednych i maluczkich, taki, jakim go sobie wyobraża wieśniak, rzeźbiący świątki dla kaplicy w jakimś zapomnianym zakątku kraju, wśród gór i lasów [...]. Dzięki niemu rzeczywistość, wykolejony świat powraca do swego odwiecznego porządku ${ }^{27}$.

Takiego jednoznacznie optymistycznego, sprawiedliwego Boga w filmie Vávry nie ma.

Postaci zostały zbudowane wokół emploi wykonawców - szczególnego rodzaju kreacje stworzyli: Karel Höger jako inżynier Prokop, Jindřich

26 Alena Becholdová, Rozhovor s národním umĕlcem Otakarem Vávrou o filmu Černé slunce, „Film a doba" 25, 1979, č. 10, s. 543.

27 Karel Krejčí, Droga życia i twórczości Karola Čapka, „Pamiętnik Słowiański” 1970, nr XX, s. 8. 
Plachý w roli d'Hemona i František Smolík, który wcielił się w postać doktora Tomeša. Rola Karela Högera uważana jest za jedną z najważniejszych w jego bogatej karierze ${ }^{28}$.

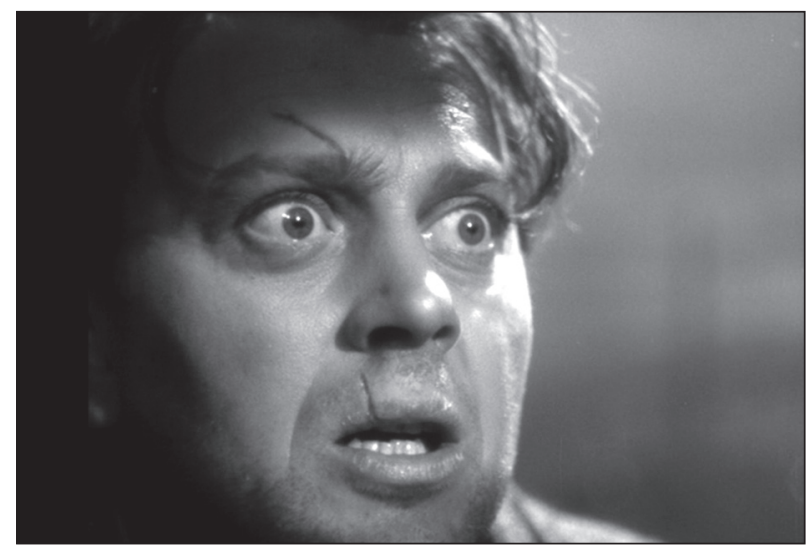

Fot. 1. Krakatit (1948, reż. Otakar Vávra)

Karel Höger w roli inżyniera Prokopa

On sam wspominał ją jako szczególnego rodzaju wyzwanie - po pierwsze, z uwagi na osobisty stosunek do prozy Čapka, a po wtóre dlatego, że uważano go raczej za amanta czeskiego ekranu, co w tym okresie utrudniało podejmowanie ambitniejszych przedsięwzięćc ${ }^{29}$. Rola inżyniera Prokopa jest niepokojąca, na pograniczu samoświadomości i obłędu, niezwykle sugestywna i budząca skrajne emocje. Rolę księżniczki Wilhelminy zagrała Florence Marly (właściwie Hana Smékalová), ówcześnie żona francuskiego reżysera Pierre'a Chenala, znanego i cenionego w okresie międzywojennym z adaptacji utworów Dostojewskiego i Pirandella. Krakatit był jedynym jej filmem nakręconym w Czechosłowacji, a późniejsza kariera aktorki na Zachodzie nie przyniosła spodziewanych sukcesów ${ }^{30}$. Jest w Krakaticie także scena niezwykła, kiedy Carlson (w tej roli nieunikający aktorskiej błazenady Eduard Linkers) prowadzi Prokopa, na przyjęciu w Baltinie, przez salę pełną nieruchomych postaci - arystokratycznych władców zbrojeniowej korporacji. Czujemy się wtedy jak w gabinecie figur woskowych. Byli to jednak żywi ludzie - Vávra odnalazł żyjących skromnie

28 Veronika Zýková, „Krakatit” a „Krakatit?!” Otakara Vávry, http://25fps.cz/2010/krakatit-a-krakatit-otakara-vavry (dostęp: 29.05.2012).

29 Karel Höger, Z hercova zápisníku, Nakladatelství XYZ, Praha 2009, s. 110-113.

30 Miloš Fikejz, Český film. Herci a herečky II díl: L-R, Nakladatelství Libri, Praha 2010, s. 134. 
na praskim Starym Mieście przedstawicieli rosyjskiej arystokratycznej rodziny Romanowych. Mimo że utrzymywali się oni z pracy w warsztacie stolarskim, przyznawali się do pokrewieństwa z carskimi antenatami i zachowali maniery rodem z Sankt Petersburga ${ }^{31}$. Całkowicie zgodną z intencjami Čapka ekranową postać stworzył František Smolík jako wiejski lekarz dr Tomeš. Sekwencje tynickie tworzą wyraźny kontrapunkt do pozostałych apokaliptycznych wizji - dom i klinika dra Tomeša są nie tylko alternatywą dla obłędnie destrukcyjnego świata wielkich korporacji zbrojeniowych, bogato wyposażonych laboratoriów produkujących śmiercionośne środki wybuchowe czy mrocznych rezydencji dekadenckich spiskowców, lecz także metaforą rustykalnego spokoju, w którym nawet najbardziej udręczony człowiek, jeżeli tylko tego chce, może odnaleźć spokój.

Scenografia opracowana przez Jana Zázvorkę jest jednolita, a jej atelierowy charakter podkreśla niesamowitość opowiadanej historii i nawiązuje do ekspresjonistycznej faktury sprzed lat, jak również wpisuje się $\mathrm{w}$ atomowy kontekst pozaekranowych niepokojów. Zázvorka, który zadebiutował jako scenograf $\mathrm{w}$ kinie Protektoratu, jeszcze wielokrotnie budował świat pełen niesamowitych kształtów, mechanizmów pozornie kontrolowanych przez człowieka, a w rzeczywistości będących potwornymi urządzeniami o antropofagicznych skłonnościach. Tak było zarówno w jednym z wczesnych czeskich filmów grozy Podobizna (1947) w reż. Jiříego Slavíčka, który powstał rok przed zrealizowaniem Krakatita, jak i w ostatnim jego projekcie - Tajemnica zamku w Karpatach (Tajemstoí hradu v Karpatech), który na ekran przeniósł w 1981 r. Oldřich Lipský. Sugestywnie wyglądały także sceny eksplozji atomowych, które zostały nakręcone na wydziale efektów specjalnych wytwórni Barrandov przy użyciu stworzonego na potrzeby filmu dwumetrowego zbiornika wodnego napełnionego różnokolorowymi płynami. Jeszcze dziesięć lat po premierze jeden $\mathrm{z}$ amerykańskich krytyków w rozmowie z reżyserem podziwiał paradokumentalny efekt, jaki w tych sekwencjach udało się osiągnąćc ${ }^{\prime 2}$.

Otakar Vávra należał do tych filmowych twórców, którzy w roku 1946 podpisali Majowa odezwę środowisk kulturalnych do czeskiego ludu, będącą $\mathrm{w}$ istocie jedną z najbardziej przemyślanych komunistycznych deklaracji przed wyborami do Zgromadzenia Narodowego. Nie uchroniło to jednak ani jego, ani innego sygnatariusza aktu, Jiříego Weissa, przed surową oceną ze strony partyjnych dyktatorów kultury. Zdeněk Nejedlý, minister eduka-

31 Otakar Vávra, Podivný život režíséra, Prostor, Praha 1996, s. 128.

32 Otakar Vávra, Pamĕti..., s. 129. 
cji i jeden z promotorów czechosłowackiego socrealizmu, uznał zarówno wcześniejsze dokonania reżysera, takie jak powstała w 1937 r. Filozoficzna historia (Filosofská historie) na postawie prozy Aloisa Jiráska, jak i Krakatit za fałszywe i niedorzeczne ${ }^{33}$. Do napiętnowania środowiska filmowego przypadek adaptacji Čapka wykorzystał także mianowany we wrześniu 1948 r. nowym dyrektorem Czechosłowackiego Filmu Państwowego Oldřich Macháček, który oskarżył dzieło o kosmopolityzm i mieszczański pacyfizm $^{34}$. Natomiast frekwencyjnie premiera była sukcesem - film pokazano jednocześnie w jedenastu stołecznych kinach, a łączna liczba wykonanych kopii przekroczyła sto ${ }^{35}$.

Przełom lat 40. i 50. w filmie czechosłowackim to dyktat młodych i niedoświadczonych filmowców, reprezentujących VI i VII grupę twórczą Czechosłowackiego Filmu Państwowego. Choć w roku 1950, po opublikowaniu wytycznych $Z a$ vy̌šsí ideovou a umĕleckou úroveň československého filmu (Ки wyższemu ideologicznemu i artystycznemu poziomowi filmu czechosłowackiego), najbardziej zagorzali dogmatycy zostali skrytykowani, to jednak poziom indoktrynacji ideologicznej do 1953 r. pozostał nie zmieniony $^{36}$. Reżyserzy z okresu pierwszej republiki: Martin Frič, Václav Kubásek, Miroslav Cikán i właśnie Vávra musieli poruszać tematy zaakceptowane przez władze, pozbawione formalnych poszukiwań i w ten sposób zerwać z tradycją, którą reprezentowali do lutego $1948 \mathrm{r}$.

Gorszy okres twórczości Otakara Vávry zakończył się w latach 60. W czasie, gdy jego nowofalowi wychowankowie z jego grupy absolutoryjnej na FAMU, opierając się na prozie Bohumila Hrabala, Milana Kundery, Arnošta Lustiga, zaczęli eksplorować tematy związane z poetyką "małego realizmu”, Vávra sięgnął po pozornie niefilmową poetycką twórczość Františka Hrubina. Zrealizował Sierpniowa niedziele (Srpnová neděle, 1960), Złotą renetę (Zlatá reneta, 1965), a przede wszystkim Romance na trąkę (Romance pro kř́dlovku, 1965). W tej ostatniej pokazał świat zwykłych spraw dziejących się na granicy jawy i snu, przeszłości i przyszłości, życia i śmierci. Opowieść o niespełnionym, gwałtownie

33 Jan Jaroš, Otakar Vávra se zasloužil o film, [w:] Otakar Vávra 100 let..., s. 175.

34 Jerzy Toeplitz, Historia sztuki filmowej VI. 1946-1953, Wyd. Artystyczne i Filmowe, Warszawa 1990, s. 353.

35 Otakar Vávra, Zamyšlení režiséra, Panorama, Praha 1982, s. 162.

36 Petr Bilík, Pisarz filmowy - autor czy stuga. O polemice między czeska literatura a filmem w latach powojennych, tłum. Lucyna Spyrka, [w:] Punkty widzenia II. Pohledy II. Strategie autorskie w czeskim i polskim teatrze i filmie, red. Tatiana Lazorčákova, Ewa Wąchocka, Wyd. Uniwersytetu Śląskiego, Katowice 2004, s. 77. 
przerwanym uczuciu w cieniu odchodzącego życia, dzięki odważnej kreacji polskiego aktora Janusza Stachowskiego była dowodem na to, że - jak określił to najbardziej sumienny kronikarz „czechosłowackiej nowej fali" Antonín J. Liehm - artysta złapał drugi oddech ${ }^{37}$. Podzwonnym dla okresu nadwełtawskiej wolności był Młot na czarownice (Kladívo na čarodejníce, 1969) - alegoryczna opowieść historyczna o XVII-wiecznych procesach w Šumperku, którą można było odczytać jako przypomnienie procesów stalinowskich i która stanowiła metaforyczne oskarżenie każdego systemu opartego na wszechwładzy, denuncjacjach, podłości.

Młota na czarownice długo nie pokazywano publiczności, a jego twórca przez cztery lata milczał, by w połowie lat 70. powrócić trylogią wojenną rekonstruującą doświadczenia czechosłowackie minionego konfliktu światowego: Dni zdrady (Dny zrady, 1973), Sokołowo (Sokolovo, 1974) i Wyzwolenie Pragi (Osvobození Prahy, 1973). Zaproponowana przez Vávrę i scenarzystę wszystkich części tryptyku Miroslava Faberę wizja została wysoko oceniona przez normalizacyjne władze, zaś źle przez późniejszych historyków filmu. Środkowa część trylogii egzystowała jednak na marginesie pozostałych, lecz nie z powodu realizacyjnej kontestacji, tylko dlatego, że odtwórca głównej roli Martin Štěpánek wyemigrował na Zachód na początku lat 80. Najbardziej nacechowane ideologicznie było Wyzwolenie Pragi, w którym twórcy całkowicie pominęli rolę Josefa Smrkovskiego, $\mathrm{z}$ uwagi na jego zaangażowanie w wydarzenia Praskiej Wiosny, a kierowana przez niego Czeska Rada Narodowa została pokazana niemal jak organizacja kolaborancka. W archiwach Barrandova zachowały się dokumenty świadczące o tym, że Vávra, który po odsunięciu starego kierownictwa czechosłowackiego filmu natychmiast zaoferował nowej władzy swoje usługi, myślał o kolejnej przygodzie z klasycznym tekstem Karela Čapka. Tym razem miał to być Meteor, ale plany nie spotkały się ze zrozumieniem kierownika zespołu twórczego Miloša Broža ${ }^{38}$.

$\mathrm{Na}$ początku lat 80. Vávra wrócił do powieści Krakatit. Tym razem było to typowe zamówienie, jakie złożył mu ówczesny dyrektor czechosłowackiej kinematografii Jiří Purš. Wezwał on reżysera i oświadczył, że otrzymał z samej góry polecenie zrealizowania filmu o „czystej bombie”, która nie niszcząc obiektów, unicestwia życie. Odpowiedzią Vávry była nowa wersja Krakatita. Produkcja była bardzo kosztowna, zaangażo-

37 A. J. Liehm, Zákazy a přikazy nevedou k ničemu, [w:] Otakar Vávra 100 let..., s. 81.

38 Štěpan Hulík, Kinematografie zapomnĕní. Počatky normalizacje ve Filmovém studiu Barrandov (1968-1973), Academia, Praha 2011, s. 218. 
wano jako współproducentów: rumuńską wytwórnię Buftea Film Bukurešt i bułgarską Kinostudio Bojana Sofia, a fragmenty scenariusza filmu wydrukowano jeszcze przed zakończeniem zdjęćc ${ }^{39}$. „Był to mój największy błąd" - oświadczył Vávra pod koniec życia ${ }^{40}$. Akcja Ciemnego słońca (Temné slunce, 1980) „naukowo-fantastycznego filmu, swobodnej adaptacji powieści Karela Čapka” nie rozgrywa się już w „fantazji gorączkowego snu", a w świecie całkowicie realnym, znanym widzowi z przekazów telewizyjnych i doniesień prasowych, którego obraz uformowały wszechobecne media. Postaci zostały przykrojone na potrzeby nie tylko nowego ideologicznego dyskursu, ale przede wszystkim tak, by odpowiadały doświadczeniom widzów z roku 1981. Prokop nie jest już jedynie inżynierem, ale legitymuje się doktoratem z fizyki jądrowej. Choć nosi kostium współczesny, to odtwórca tej roli, Radek Brzobohatý, z trudem odrywał się od kreacji stworzonej ponad trzydzieści lat wcześniej przez Karela Högera. Niektóre sceny stanowiły wręcz kopie wcześniejszych sekwen$\mathrm{cji}^{41}$. Trudno orzec, czy ten efekt był spowodowany ograniczeniami scenariusza, czy też nadmiarem obowiązków, jakim popularny aktor musiał sprostać w tym czasie ${ }^{42}$. Sam Brzobohatý odżegnywał się od takich konstatacji, twierdząc, że kreacji Karela Högera nie można podrobić. W niektórych wywiadach prezentował nawet kontrapunktową interpretację: bohater adaptacji z 1948 r. jest intelektualistą, zaś w jego koncepcji bliski był zwykłemu życiu. Podobno proces tworzenia ekranowej sylwetki inżyniera Prokopa trwał nawet $\mathrm{w}$ trakcie zdjęć, a niektóre propozycje aktora zyskały akceptację zarówno Vávry, jak i współscenarzysty Jiříego Šotoli ${ }^{43}$. Owcześni krytycy dostrzegli w kreacji Brzobohatego odmienne od Čapkowych cechy: romantyczne uniesienie, pełne gwałtowności i nieprzewidywalności, w jakie wyposażony był inżynier Prokop z powieści, zastąpione zostało pewnością siebie, stanowczością i wiarą w potęgę akademickiej wiedzy, która połączona z oligarchicznym kapitałem może zapewnić władzę nad światem ${ }^{44}$. Paradygmat demonicznego przemysłu zbrojeniowego, charakteryzującego pragmatykę stosunków amerykańsko-radzieckich

39 Jiří Šotola, Otakar Vávra, Černé slunce, „Film a doba” 25, 1979, č. 10, s. 546-555 (fragment scenariusza, cztery fotografie).

40 Helena Herbrychová, Mưj život był film, [w:] Otakar Vávra 100 let..., s. 120.

41 Robert Kolař, Hledání Prokopa a dalšich postav Radoslava Brzobohatého, "Záběr" 13, 1980, č. 3, s. 8 .

42 Robert Rohál, Krasavci filmového nebe, Petrklíč, Praha 2009, s. 45.

43 Jiří Novák, Na Barrandove se nakrúcalo Černé slunce. Nový Krakatit. Rozhovor s R. Brzobohatým, „Film a divadlo" 24, 1980, č. 1, s. 6.

44 Václav Vondra, Temné slunce - Vávrovo memento, „Kino” 35, 1980, č. 13, s. 5. 
na przełomie lat 70. i 80. XX w., zmienił też cechy pozostałych postaci: nie ma zatem księżniczki Wilhelminy, dziedziczki arystokratycznego imperium Baltin, pojawia się zaś bratanica szefa firmy Atlantik - Kris, w którą wcieliła się słowacka aktorka Magda Vašáryová, nagrodzona zresztą za tę rolę na XIX Festiwalu Filmów Czechosłowackich w Kladnie ${ }^{45}$. Ta, ówcześnie trzydziestoletnia, odtwórczyni głównej postaci kobiecej nie tylko miała już na swoim koncie znaczące osiągnięcia artystyczne, jak choćby tytułową kreację w filmie Františka Vláčila Małgorzata, córka Eazarza (Marketá Lazarová, 1967), lecz także złożyła swój podpis pod Antykartą - deklaracją czeskich i słowackich intelektualistów potępiającą działania coraz aktywniejszych środowisk dysydenckich. Zresztą nie była jedyną w ekipie Ciemnego słońcaAntykartę podpisali również: reżyser Otakar Vávra, aktorzy Rudolf Hrušinský, Luděk Munzar czy scenarzysta Jiř́i Šotola. Wśród aktorów znalazło się też sporo wykonawców z krajów obozu socjalistycznego: Jerzy Kamas jako ambasador Dai Mon, Nóra Németh i András Bálint z Węgier czy reprezentujący kinematografię Niemieckiej Republiki Demokratycznej Günter Naumann, znany z popularnego serialu kryminalnego Polizeiruf 110.

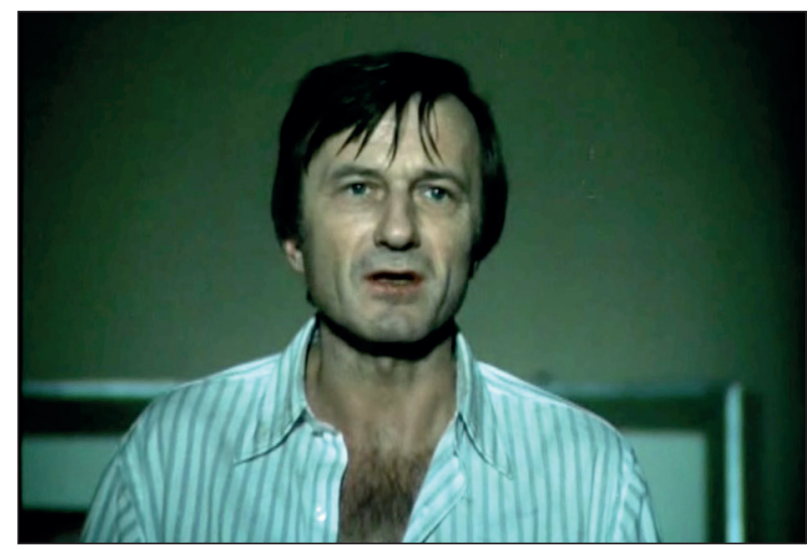

Fot. 2. Ciemne słońce (1980, reż. Otakar Vávra) Radek Brzobohatý w roli inżyniera Prokopa

Świat przedstawiony przypomina, jak wcześniej wspomniałem, obrazy znane $\mathrm{z}$ ówczesnych propagandowych przekazów telewizyjnych: demonstracje antyatomowe, industrialne przestrzenie tętniące produk-

45 Faktycznie nagroda została przyznana również za drugą kreację aktorki w filmie J. Menzla Postrzyżny, patrz: Český hraný film V. 1971-1980. Czech Feature Film V. 1971-1980, Národní Filmový Archiv, Praha 2007, s. 424. 
cyjnym życiem, akcje terrorystyczne. Arystokratyczną korporację Baltin zastąpiły laboratoria Atlantiku - ponadnarodowej firmy zbrojeniowej zorientowanej na wywołanie globalnego konfliktu. $\mathrm{W}$ tej pozornie nieistotnej modyfikacji widoczne jest nacechowanie związane z czasem poza diegezą filmu. Atlantic to odpowiednik NATO - Organizacji Traktatu Północnoatlantyckiego, złowrogiego spisku antypokojowego sięgającego początków zimnej wojny na przełomie lat 40. i 50. Potwierdza to, niemająca swego literackiego odpowiednika, rozbudowana sekwencja posiedzenia rady nadzorczej Altantiku, podczas którego Carson (Rudolf Hrušinský) rozpisuje w postaci wzoru algebraicznego spodziewane straty po stronie nieprzyjaciela. Ponadto scena porwania samolotu, którym Prokop i Dai Mon udają się do ośrodka badań firmy, przywołuje szeroko komentowany w prasie końca lat 70. przypadek wnuczki i dziedziczki fortuny magnata prasowego Williama Randolpha Hearsta, Patty, która po porwaniu przyłączyła się do komanda niewielkiego ugrupowania terrorystycznego tzw. Rewolucyjnej Armii Symbiozy i wraz z pozostałymi terrorystami uczestniczyła w akcjach ekspropriacyjnych. Kris jest ekranową eksplikacją Patty Hearst, ale jej motywacje trudno wpisać w syndrom sztokholmski, którym to stanem, uzależniającym ofiary od swoich prześladowców, tłumaczono zachowanie porwanej - wszak w scenie pożegnania z Prokopem, kiedy mijają pacyfistycznych demonstrantów, mówi wyraźnie: chodź ze mna, będziemy się mścić, za tę straszliwa nudę. Znudzeniem konsumpcją materialnych dóbr, posiadaną pozycją i pogardą dla pracujących tłumaczy zatem Vávra neolewicową kontestację lat 70. Jak napisał cytowany wyżej recenzent tygodnika „Kino” Václav Vondra: „nie ma tu niczego, czego nie znalibyśmy z gazet i radia, co nie mogłoby spotkać nas za rok czy za dziesięć lat" ${ }^{\prime \prime 46}$.

Jedną z najbardziej brawurowych scen jest, wyraźnie stylizowana na Hair (1979) Miloša Formana, sekwencja antywojennej demonstracji, z piosenką Válku válce, którą do słów Jiř́iego Šotoli skomponował Martin Kratochvíl, a wykonał założony przez niego zespół Jazz Q. Pacyfistyczny film Formana znany był w krajach Europy Środkowej, a jeden z operatorów Ciemnego słońca - Miroslav Ondříček - był autorem zdjęć do niego. Trudno orzec, czy ten swoisty cytat ma podtekst ironiczny, czy też stanowi osobliwy wkład Ondříčka w ostateczny kształt tego nieudanego filmowego przedsięwzięcia. Zresztą nie wytrzymał on na planie Ciemnego słońca zbyt długo, bowiem po wpadce $\mathrm{z}$ eksplozją filmowych zakładów Atlantik, kręconą na lotnisku w Prešovie, kiedy z poparzoną ręką trafił do szpitala

${ }^{46}$ Václav Vondra, dz. cyt. 
w Koszycach, zrezygnował ze współpracy z Vávrą, a za kamerą zastąpił go Josef Illík ${ }^{47}$. Miroslav Ondříček zakończył w ten sposób współpracę z czechosłowacką kinematografią.

Omawiając sylwetkę Otakara Vávry w popularnym leksykonie wydanym w połowie lat 80. ubiegłego wieku Českoslovenští filmoví režiséři sedmdesátých let Jiří Levý tak wzmiankował jego powrót do Čapkowego literackiego oryginału:

znowu, ale jeszcze wyraźniej przestrzega on zarówno przed terrorystami, jak i hegemonizmem kręgów imperialistycznych usiłujących doprowadzić świat do grozy wojny atomowej, a jednocześnie pokazuje siły pokoju, które dziś składają się z uczonych, świadomych odpowiedzialności za swą pracę ${ }^{48}$.

Kontekst zimnowojennej konfrontacji okazał się zatem kluczowy dla zastosowanych metafor. Jednak nieoczekiwanie twórcy filmu zbliżyli się do granic autoparodii - ideologiczne ostrze skierowane przeciw definiowanym demonicznie imperialistom w zbyt oczywisty sposób wykorzystywało retorykę wyjętą żywcem $\mathrm{z}$ wyśmiewanych stereotypowych wyobrażeń: „Radosław Brzobohatý po omacku błąka się po świecie niekomunistycznego Zachodu, którego uwodzicielski, wypucowany urok jest jedynie blichtrem, pod którym skrywa się hulaszczość i bezwzględność, gdzie zupełnie nie liczą się sumienie i honor, a wszystko nikczemnie przelicza się na pieniądze $\mathrm{e}^{\prime \prime 49}$. Już w momencie realizacji filmu pojawiły się głosy, że „taka nachalna aktualizacja powieści Karela Čapka spowoduje, iż Ciemne słońce nie zabrzmi jak ostrzeżenie, ale wywoła konsternację, lub co gorsza efekt komiczny" ${ }^{\prime 50}$. Jednak większość branżowych publicystów starała się nie atakować Vávry, chwaląc go za uwspółcześnienie literackiego pierwowzoru. Zdeněk Zaoral, ówcześnie wykładowca na FAMU, napisał w dzienniku Czechosłowackiej Partii Socjalistycznej „Svobodné slovo”, że udało się powieść Karela Čapka wykorzystać do postawienia spraw zarówno uniwersalnych, jak i dotyczących aktualnych społecznych realiów ${ }^{51}$. Po la-

47 Otakar Vávra, Zamyšlení..., s. 253. Josef Illík wcześniej współpracował z Vávrą przy realizacji Młota na czarownice (1969).

48 Jiří Levý, Českoslovenští filmovi režiséri sedmdesátých let, Československý Filmový Ústav, Praha 1983, s. 90.

49 Jan Jaroš, dz. cyt., s. 196.

50 Diskuse. Hrdina ve filmu, literatuře, televizi a filmu, „Film a doba” 1981, č. 9, s. 488 (přispĕvek Vladimíra Kolára).

51 Zdenĕk Zaoral, Aktualizovaný Karel Čapek, „Svobodné slovo” 36, č. 240, s. 5. 
tach przewaga akcentów publicystycznych nad adaptacyjnymi nie budziła żadnych wątpliwości. Przeciwstawiając film Vávry ekranizacjom prozy Vladimíra Párala, które w latach 80. zrealizowali - wbrew normalizacyjnym dyrektywom - Jaromil Jireš i Vladímir Drha, Brigita Ptáčková uznała, że Ciemne słońce aktualizuje prozę Čapka w duchu prosowieckiej antyatomowej kampanii, choć akcję umieszcza w nieokreślonej bliżej przyszłości, podobnej do tej, jaką czescy widzowie znali z większości zwariowanych komedii (bláznivá komedie), charakterystycznych dla kina normalizacji52. To dość ciekawa uwaga, zważywszy na szczególny status, jaki miały i popularność, jaką się cieszyły filmy takich twórców zwariowanych komedii, jak Václav Vorlíček, Oldřich Lipský czy Jindřich Polák. Fantastyka naukowa czy baśniowa wykorzystywana była dla pokazania sytuacji, jakich poza tym gatunkiem kino czechosłowackie lat 70. i 80. eksponować nie mogło - łapówkarstwa, prostackiego konsumpcjonizmu i nadużywania władzy. Osadzenie w podobnej scenerii czasoprzestrzennej akcji Ciemnego słońca mogło zatem wywołać niezamierzony efekt w postaci ironicznego odczytania filmu. Wspomniany na początku tekstu Josef Škvorecký nie omieszkał też wystawić swojej cenzurki:

Ciemne słońce to historia współczesna, zgodna z wyświechtaną tradycją przedstawiającą obóz sowiecki jako miłujący pokój, pełen gołębiej łagodności i sprawiedliwy raj, przeciwstawiony światu zachodnich wojennych podżegaczy, którzy uzbrojeni po zęby, nieustannie knują by wywołać kolejny światowy konflikt. Jednoznacznie czarno-biały świat tego kolorowego filmu zmienił opowieść starego humanisty Čapka w grubo ciosaną neostalinowską propagandę, a rezultat był tak potworny, że jak wieść niesie, załamywało nad nim ręce nawet partyjne kierownictwo wytwórni na Barrandovie $^{53}$.

Takie były dwie interpretacje powieści Karela Čapka dokonane przez Otakara Vávrę. On sam był wszechstronnym reżyserem i scenarzystą, ale rozdartym między miłością do kina i lojalnością wobec reżimu. Obok wielkich dzieł, takich jak: Krakatit, Młot na czarownice czy Romanca na trąbkę, kręcił filmy, które w najlepszym wypadku można uznać za nieporozumienia twórcze, a wśród nich Ciemne słonce zajmuje czołowe miejsce. Nazywano go żyjącą legendą nadwełtawskiego kina, ale także wielkim inkwizytorem, geniuszem przeciętniactwa, mistrzem kamuflażu, Salierim czeskiego

\footnotetext{
52 Brigita Ptáčková, Hraný film v obdobi normalizace (1970-1989), [w:] Panorama českého filmu..., s. 161.

53 Josef Škvorecký, dz. cyt., s. 207.
} 
filmu, Rasputinem z Barrandova i po prostu łajdakiem bez moralnego kręgosłupa $^{54}$. Dość dobrze oddaje przypadek Otakara Vávry opinia, jaką wypowiedział podczas dyskusji z okazji setnej rocznicy jego urodzin, w redakcji „Lidových novin”, jeden z obecnych profesorów FAMU, historyk kina, dyrektor Narodowego Archiwum Filmowego w Pradze, dr Michal Bregant: „Chciał kręcić wielkie filmy. Uważał, że jest kimś więcej niż najwybitniejszym tuzem czechosłowackiej kinematografii. W swoich oczach on sam tą kinematografią by1" ${ }^{\prime \prime 5}$.

54 Jaromír Blažejovský, Dobové tance kolem života a díla Otakata Vávry, [w:] Studia Moravica VI Symposiana, "Acta Universitatis Palackianae Olomucensis. Facultas Philosophica”, Univerzita Palackého v Olomouci, Olomouc 2008, s. 229.

55 Michal Bregant, Ondřej Štindl, Jiř́i Peňás, Jakub Felcman, Miroslav Bambušek, Legenda o fachmanowi, který vždy vitéži, „Lidové noviny” 2010, č. 56, s. 8. 